\title{
PHYLOGENETIC RELATIONSHIPS OF THE PLAGUSIIDAE DANA, 1851 (BRACHYURA), WITH DESCRIPTION OF A NEW GENUS AND RECOGNITION OF PERCNIDAE ŠTEVČIĆ, 2005, AS AN INDEPENDENT FAMILY
}

\author{
BY \\ CHRISTOPH D. SCHUBART ${ }^{1,3}$ ) and JOSÉ A. CUESTA ${ }^{2,4}$ ) \\ 1) Biologie I, Universität Regensburg, D-93040 Regensburg, Germany \\ 2 ) Instituto de Ciencias Marinas de Andalucía, CSIC, Avenida República Saharaui, 2, \\ E-11519 Puerto Real, Cádiz, Spain
}

\begin{abstract}
A molecular and morphological analysis of representatives of the family Plagusiidae, including all members of Plagusia Latreille, 1804, and the recently established Davusia Guinot, 2007, was carried out. Due to marked differences in adult and larval morphology, as well as mitochondrial and nuclear DNA, two species of Plagusia, viz., P. chabrus (Linnaeus, 1758), and $P$. dentipes De Haan, 1835, are considered sister taxa but distinct from other members of the genus. They are transferred to a new genus, Guinusia. A molecular phylogeny suggests that Guinusia is not closer related to Plagusia than to the plagusiid genera Euchirograpsus H. Milne Edwards, 1853, and Miersiograpsus Türkay, 1978. Furthermore, with new evidence from mitochondrial and nuclear DNA as well as a reappraisal of the larval morphology, the genus Percnon Gistel, 1848, is formally removed from the Plagusiidae and recognized as a separate family, Percnidae Števčić, 2005.
\end{abstract}

\section{RÉSUMÉ}

Une analyse moléculaire et morphologique des représentants de la famille des Plagusiidae comprenant tous les membres du genre Plagusia Latreille, 1804, et le genre récemment établi Davusia Guinot, 2007, a été réalisée. Pour tenir compte des nettes différences dans la morphologie adulte et larvaire ainsi que sur l'ADN nucléaire et mitochondrial, deux espèces de Plagusia, $P$. chabrus (Linnaeus, 1758), et $P$. dentipes De Haan, 1835, sont considérées comme espèces sœurs et transférées dans le genre Guinusia. Une phylogénie moléculaire suggère que ce genre n'est pas plus proche du genre Plagusia que des genres de Plagusiidae Euchirograpsus

\footnotetext{
${ }^{3}$ ) Corresponding author; e-mail: christoph.schubart@biologie.uni-regensburg.de

${ }^{4}$ ) e-mail: jose.cuesta@icman.csic.es
} 
H. Milne Edwards, 1853 et Miersiograpsus Türkay, 1978 et justifie donc sa séparation. Par ailleurs, considérant les nouvelles preuves des l'ADN mitochondriaux et nucléaires et une réévaluation de la morphologie larvaire, le genre Percnon Gistel, 1848 est ici formellement enlevé de la famille des Plagusiidae et placé dans une famille propre, les Percnidae Števčić, 2005.

\section{INTRODUCTION}

The genus Plagusia Latreille, 1804, underwent a period of taxonomic confusion and re-definitions towards the end of the $19^{\text {th }}$ century (Miers, 1878; De Man, 1883; Alcock, 1900; see Schubart \& Ng, 2000), but this largely stabilized with the monograph by Rathbun (1918). The modern composition of the genus, and the status of species (and subspecies) were more recently summarized by Dawson (1987) and Schubart \& Ng (2000). Schubart et al. (2001) addressed the issue of the subspecific status within Plagusia depressa (Fabricius, 1775), and recognized Plagusia squamosa (Herbst, 1790) (formerly referred to as $P$. depressa tuberculata Lamarck, 1818, see Schubart $\& \mathrm{Ng}, 2000)$ as a full species. Guinot (2007) then removed P. glabra Dana, 1851, from Plagusia and placed it in a new genus, Davusia. This left seven species of Plagusia and unclear phylogenetic relationships among the genus Davusia and the remaining members of the family Plagusiidae.

The higher classification of Plagusia and its allies has also experienced recent changes. The description of the larval stages of Euchirograpsus americanus A. Milne-Edwards, 1880, by Wilson (1980) and Plagusia depressa by Wilson \& Gore (1980) revealed close morphological similarities between these species, which at that time were classified in different subfamilies of the family Grapsidae, i.e., Varuninae H. Milne Edwards, 1853, and Plagusiinae, respectively. Cuesta \& Schubart (1997) discussed the subfamilial arrangement based on larval morphology and confirmed that the larvae of Euchirograpsus were more closely related to Plagusia then to those of the subfamily Varuninae. They also cited unpublished evidence from mitochondrial DNA for a close phylogenetic relationship between these two genera, suggesting a "systematic position of E. americanus in close relationship to P. depressa and not linked to the main group of the Varuninae" (Cuesta \& Schubart, 1997: 296). Sternberg \& Cumberlidge (2000) had come to a similar conclusion in a morphological cladistic analysis, with Guinot \& Bouchard (1998) having previously noted that the morphology of the male abdominal press-button locking mechanism of Euchirograpsus suggested that this genus was misplaced in the Varuninae. The molecular results stated in Cuesta \& Schubart (1997) were 
published by Schubart et al. (2000), officially transferring Euchirograpsus to the Plagusiidae: "The Plagusiinae, next to the type genus Plagusia, would now also include Euchirograpsus (see also d'Udekem d'Acoz, 1999) and the taxonomic position of Percnon awaits future comparisons (i.e., incertae sedes [sic])" (Schubart et al., 2000: 184). The inclusion of Euchirograpsus within the Plagusiidae was reiterated by Schubart et al. (2002), and a similar fate was suggested for Miersiograpsus. This was confirmed by Davie (2002), who after examining adult morphology, independently transferred Miersiograpsus to the Plagusiidae giving the evidence of fused abdominal somites 3-6 as an autapomorphy for Euchirograpsus, Miersiograpsus, and Plagusia. Also around this time, two papers argued that the former grapsid subfamilies should be raised to family level (Schubart et al., 2000; Sternberg \& Cumberlidge, 2000) returning to a taxonomic system that initially Guinot (1978) had put forward, but was not followed in later classifications.

The position of Percnon within the Plagusiinae or Plagusiidae has also been questioned repeatedly (Schubart et al., 2000, 2006). Consequently, Števčić (2005) established a new tribe for the genus, Percnini, which was later adopted as a subfamily Percninae within the Plagusiidae by Ng et al. (2008). Published molecular results have placed representatives of Percnon (i.e., P. gibbesi (H. Milne Edwards, 1853) and P. planissimum (Herbst, 1804)) in a polyphyletic relationship to other members of the family Plagusiidae (see Schubart et al., 2000, 2006).

In the present contribution, we use phylogenetic analyses based on adult and larval morphology, as well as mitochondrial and nuclear DNA, to examine intrageneric relationships within Plagusia, and intergeneric relationships among plagusiid and potentially related genera. Our results show that there is sufficient morphological and molecular diversity within the genus Plagusia, that a new genus can be described for two of its constituent species. In addition, Percnon is officially removed from the Plagusiidae and placed in its own family within the Thoracotremata. The superfamily Grapsoidea is avoided in this context following the reasoning of Schubart et al. (2006) and new evidence based on nuclear DNA markers by Landstorfer et al. (unpubl.).

\section{MATERIAL AND METHODS}

Specimens examined are deposited in museums as listed in table I. New DNA sequences were obtained between 1999 and 2009. DNA extractions and selective amplification of mitochondrial and nuclear DNA were carried out 
as reported in Schubart et al. (2006). PCR-amplifications of the 16S rDNA were run with four minutes denaturation at $94^{\circ} \mathrm{C}, 40$ cycles with $45 \mathrm{~s} 94^{\circ} \mathrm{C}$, $1 \mathrm{~min} .48^{\circ} \mathrm{C}, 1 \mathrm{~min} .72^{\circ} \mathrm{C}$ and $10 \mathrm{~min}$. final denaturation at $72^{\circ} \mathrm{C}$, and the primers 16L2 or 16L29 and $16 \mathrm{H} 2$ or $16 \mathrm{HLeu}$ (see Schubart, 2009). In addition, nuclear DNA of the histone $\mathrm{H} 3$ gene was obtained for at least one specimen of all key taxa with a cycling program of $30 \mathrm{~s} 94^{\circ} \mathrm{C}, 30 \mathrm{~s} 48^{\circ} \mathrm{C}, 30 \mathrm{~s} 72^{\circ} \mathrm{C}$ (otherwise as above) and the primers H3af and H3ar (Colgan et al., 1998). PCR products were purified with Microcon 100 filters (Microcon) or QuickClean (Bioline) and subsequently sequenced with the ABI BigDye terminator mix followed by electrophoresis in an ABI Prism 310 Genetic Analyzer (Applied Biosystems, Foster City, CA, U.S.A.). New sequence data were submitted to the European molecular database EMBL (see table I for accession numbers). In addition, the following $16 \mathrm{~S}$ mtDNA ingroup sequences archived in molecular databases were included in our analyses: Guinusia dentipes (as Plagusia dentipes AJ308421), Plagusia depressa (AJ250649, AJ311791AJ311793), Plagusia squamosa (AJ311794-AJ311796), Percnon planissimum (AM180693) in addition to Genbank sequences for outgroups (see table I).

The model of DNA substitution that fitted our data best was determined using the software MODELTEST 3.6 (Posada \& Crandall, 1998). Two methods of phylogenetic inference were applied to our dataset: Bayesian Inference (BI) as implemented in MrBayes v. 3.1 (Huelsenbeck \& Ronquist, 2001) and Minimum Evolution (ME) as implemented in MEGA 4.1 (Tamura et al., 2007) with pairwise deletions, the Maximum Composite Likelihood model, heterogeneous pattern among lineages, and gamma distributed rates among sites. Gamma shape was established and BI trees were calculated using the suggested model of evolution by MODELTEST. The Bayesian analysis was run with four MCMC (Markov chain Monte Carlo) chains for 2000000 generations, saving a tree every 500 generations (with a corresponding output of 4000 trees) and with Carpilius sp. as the outgroup. The $-\ln \mathrm{L}$ converged on a stable value between 15000 and 20000 generations (burn-in phase) so that the first 25000 generations were always excluded from the analysis to optimize the fit of the remaining trees. The posterior probabilities of the phylogeny were determined by constructing a 50\% majority-rule consensus of the remaining trees. ME confidence values were established by running 2000 bootstrap pseudoreplicates.

The mitochondrial dataset consisted of 43 sequences resulting in 675 aligned characters, of which 322 were conserved, 249 parsimony-informative, and 350 variable. GTR $+\mathrm{G}+\mathrm{I}$ was selected as the best-fitting evolutionary 


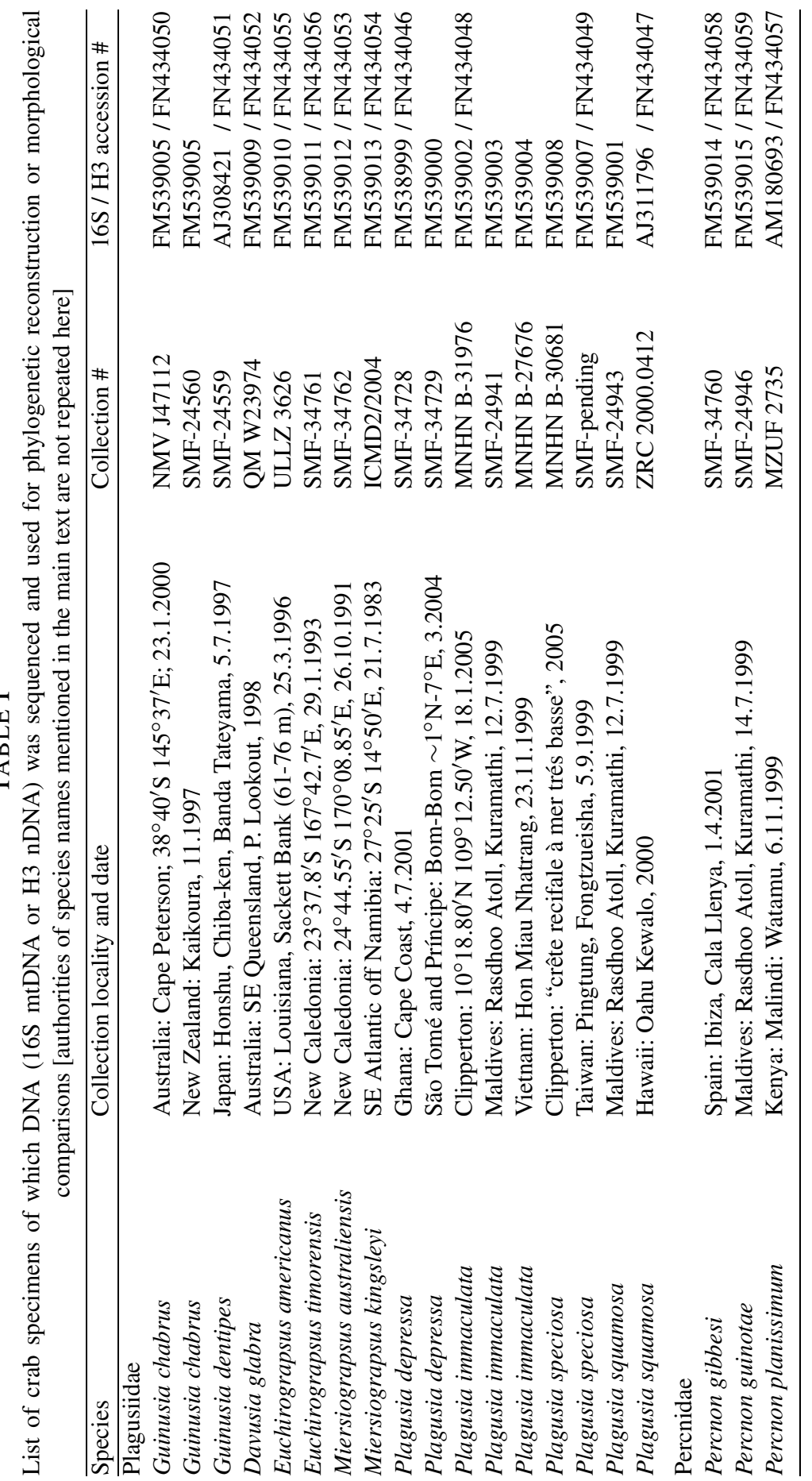




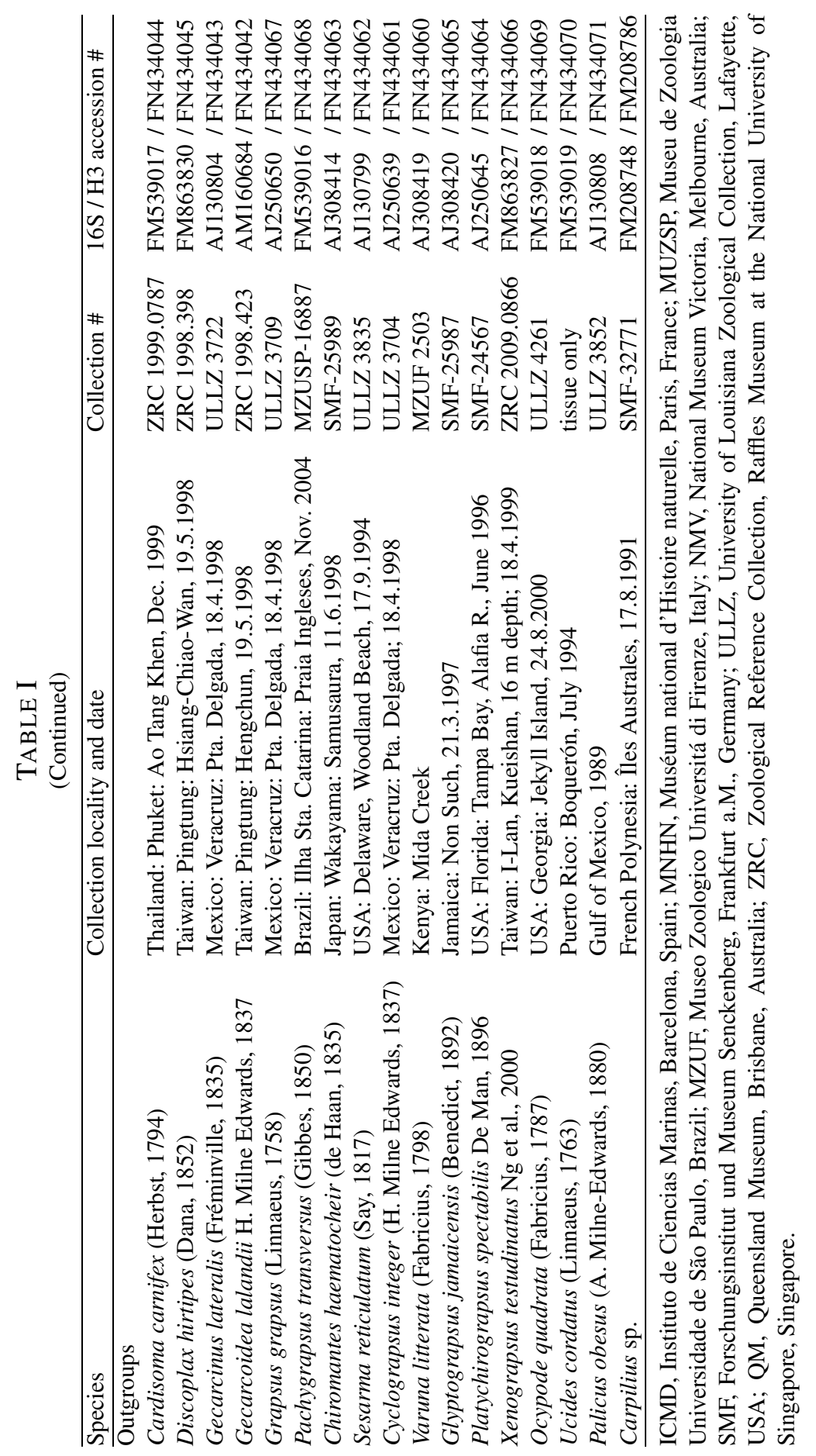


model by MODELTEST and implemented for subsequent Bayesian analysis. The ME bootstrap consensus tree resulted in an identical topology for all significant nodes. This topology with confidence values of both methods exceeding 50\% is shown in fig. 1. The histone $\mathrm{H} 3$ nuclear dataset consisted of 31 taxa with a fixed length (no indels) of 328 basepairs. It was added to the $16 \mathrm{~S}$ alignment for combined evidence, resulting in an alignment of 1003 basepairs (544 were conserved, 322 parsimony-informative, and 456 variable). Again, GTR $+\mathrm{G}+\mathrm{I}$ was selected as the best-fitting evolutionary model by MODELTEST and implemented for subsequent Bayesian analysis. The resulting consensus tree with $\mathrm{BI}$ and ME topologies exceeding $50 \%$ is shown in fig. 2.

\section{SYSTEMATIC ACCOUNT}

\section{Family PlagusiIdae Dana, 1851}

Plagusinae [sic] Dana, 1851: 288; 1852: 333, 368.

Plagusiinae - Miers, 1878: 147; Alcock, 1900: 289, 436; Guinot, 1978: 285; 1979: 106, 144, 151, 155, 206, 209; Manning \& Holthuis, 1981: 238; Williams, 1984: 462; Hartnoll, 1992: 51; Ng, 1998: 1139; Guinot \& Bouchard, 1998: 664. [All partim.]

Plagusiidae - Schubart et al., 2000: 183-184; Von Sternberg \& Cumberlidge, 2000: 120, 133; Martin \& Davis, 2001: 75; Ng et al., 2001: 47; Schubart et al., 2002: 29; Davie, 2002: 436; Števčić, 2005: 126; Schubart et al., 2006: 193, 198; Ng et al., 2008: 30, 218. [All partim.]

Type genus. - Plagusia Latreille, 1804 (type species Cancer depressus Fabricius, 1775, by monotypy and designation by Latreille, 1810: 422). Gender feminine.

\section{Guinusia n. gen.}

Plagusia — Dana, 1852: 370-371 (pro parte); Miers, 1878: 148, 152-153 (pro parte); Rathbun, 1918: 336-337 (pro parte); Barnard, 1950: 134-137 (pro parte); Griffin, 1968: 209-213; Benech, 1978: 104; Guinot, 1979: 144, 151, 209 (pro parte); Wear \& Fielder, 1985: 7376; Dawson, 1987: 37-44; Guinot \& Bouchard, 1998: 664 (pro parte); González-Gordillo et al., 2000: 144-149 (pro parte); Schubart \& Ng, 2000: 334 (pro parte); Guinot, 2007: 30 (pro parte).

(Not Plagusia Latreille, 1804.)

Type species. - Guinusia chabrus (Linnaeus, 1758) new combination, described as Cancer chabrus Linnaeus, 1758 , by present designation. Gender feminine.

Other species included. - Guinusia dentipes (De Haan, 1835) new combination, described as Grapsus (Plagusia) dentipes De Haan, 1835.

Etymology. - This genus is dedicated to our esteemed and admired colleague Danièle Guinot in recognition for her decisive contributions to the understanding of the Brachyura, her Thoracotremata, the family Plagusiidae, and the genus Plagusia. Her recent recognition of Davusia as a new genus 

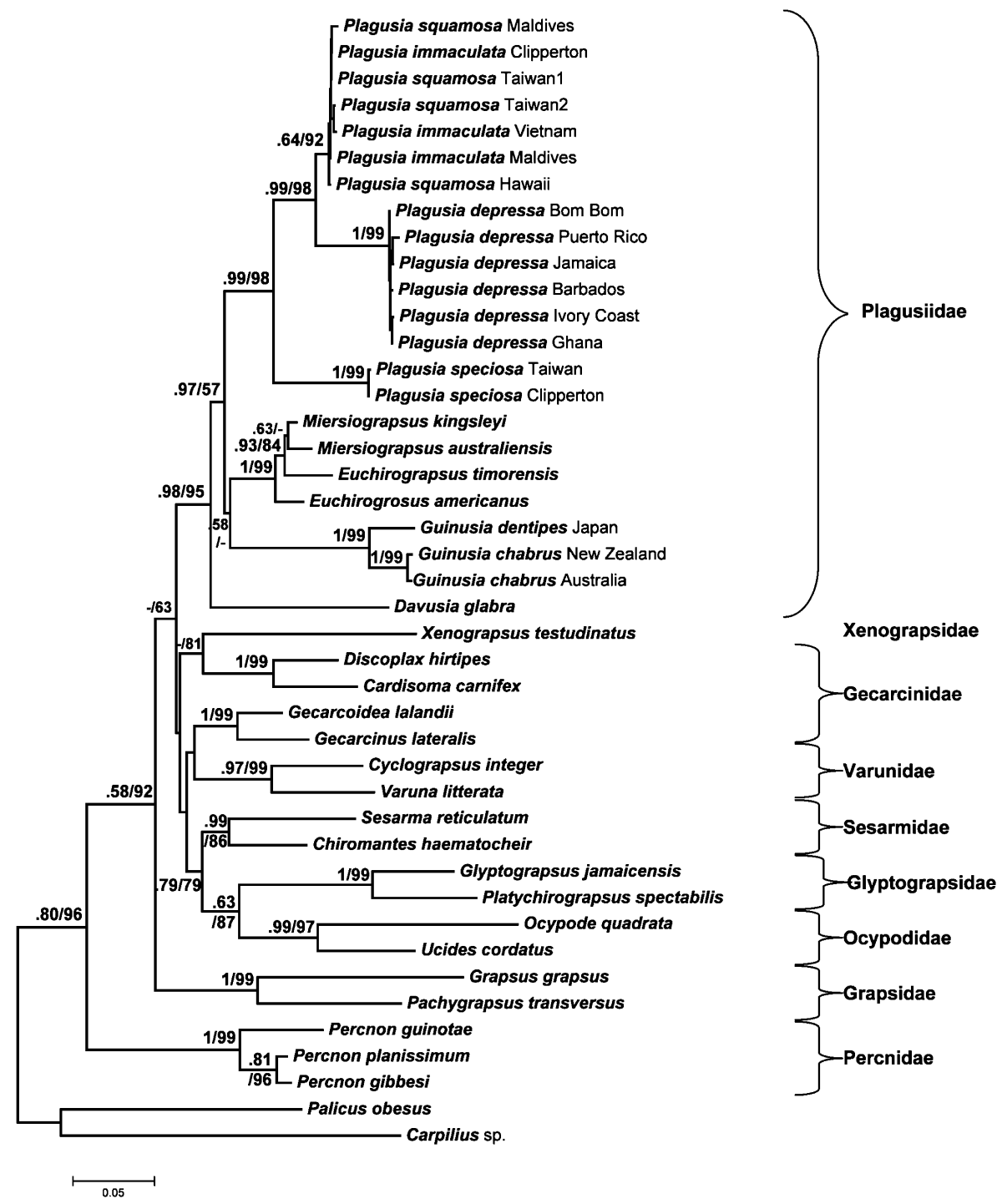

Fig. 1. Phylogenetic consensus tree of representatives of the Plagusiidae and thoracotreme outgroups based on 675 basepairs of mtDNA (16S rRNA). Bayesian Inference (BI) and Minimum Evolution (ME) confidence intervals (only $\geqslant 50$ ) corresponding to BI posterior probabilities/ME bootstrap values. Carpilius sp. was used as outgroup.

triggered the finalization of this long-planned study. The genus name is composed of the four initial letters of Danièle Guinot's last name in addition to the ending usia, expressing morphological similarity to the genera Plagusia and Davusia. Gender feminine. 


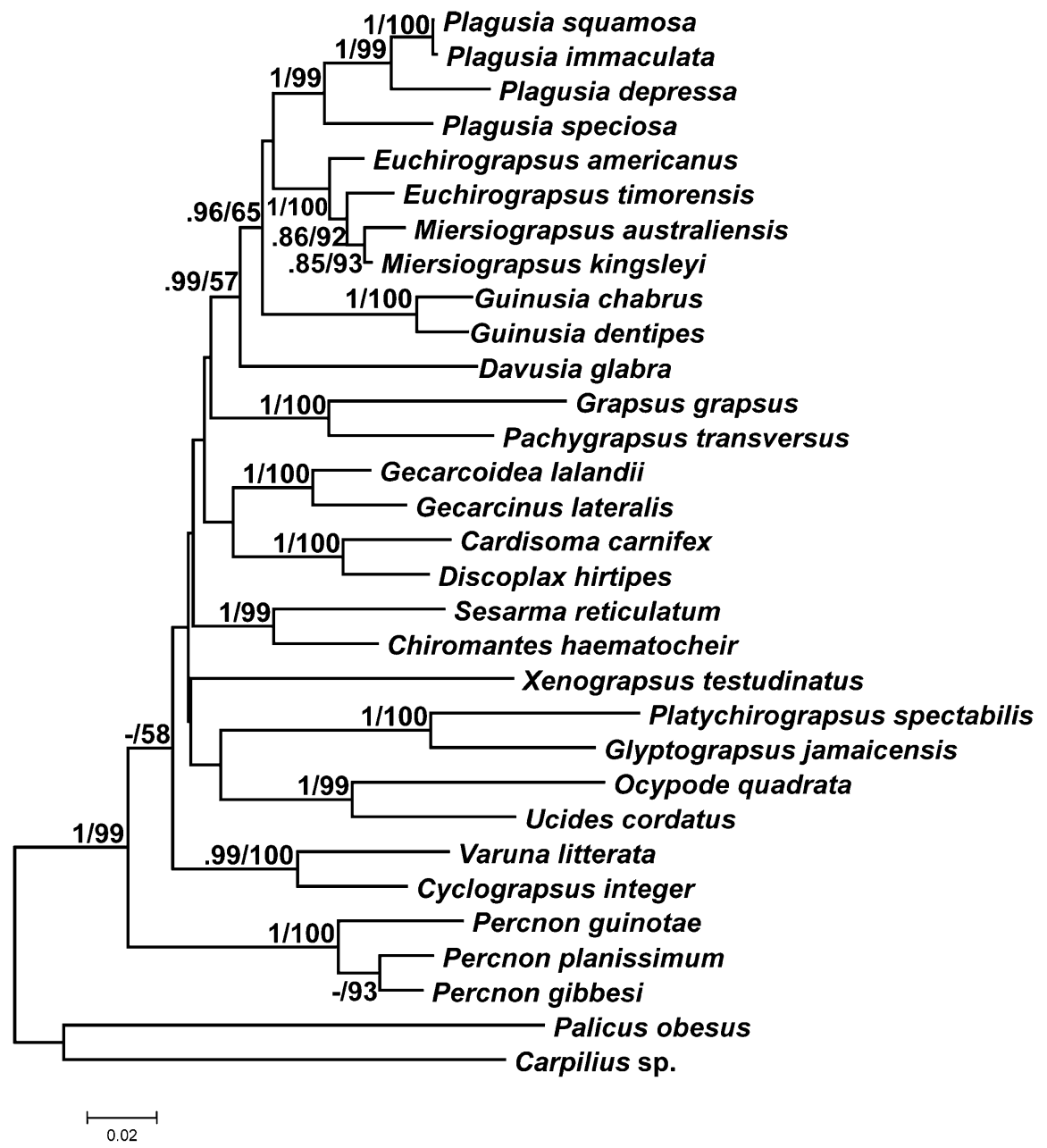

Fig. 2. Phylogenetic consensus tree of representatives of the Plagusiidae and thoracotreme outgroups based on 1003 basepairs (bp) of combined DNA (675 bp 16S rRNA, 328 bp histone H3). Bayesian Inference (BI) and Minimum Evolution (ME) confidence intervals (only $\geqslant 50$ ) corresponding to BI posterior probabilities/ME bootstrap values. Carpilius sp. was used as outgroup.

Diagnosis. - Joints of the meri of all ambulatory legs with a series of spines on their upper margin (as opposed to one subterminal and one terminal spine in Plagusia) (fig. 3). Carapace almost entirely destitute of tubercles (as opposed to tuberculate in Plagusia) (fig. 4). Larval characters as listed in table II. Other studied characters not differentiating diagnostically from Plagusia.

Remarks. - Guinot (2007) lists a number of characters that separate her new genus Davusia from the remaining species of Plagusia. One of these 


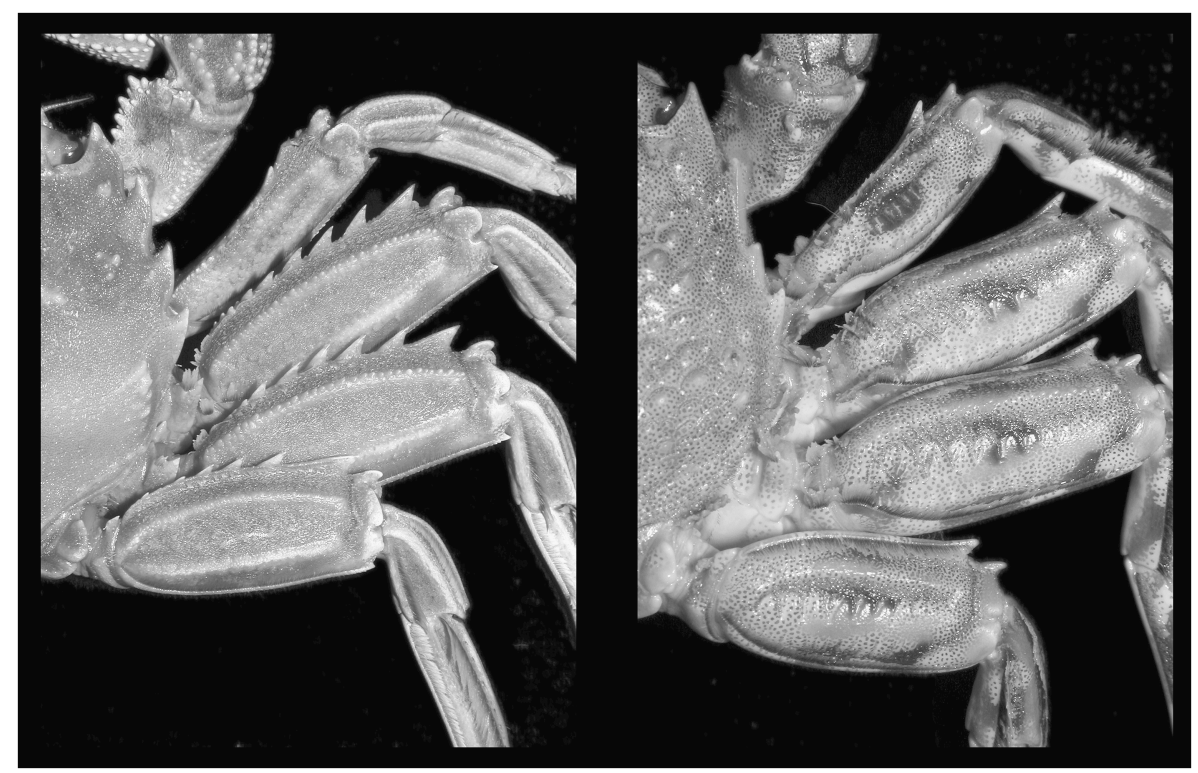

Fig. 3. Morphology of meri of walking legs in Guinusia gen. n. and Plagusia. Left, Guinusia dentipes (De Haan, 1835), Japan (SMF-24559); Right, Plagusia depressa (Fabricius, 1775) Ghana (SMF-34728).

characters is the presence of a palp on the exopods of the third maxillipeds. This palp is absent in the other species of Plagusia, except for P. dentipes, where it may be present in the form of a flagellum. She then concludes that "the generic position of $P$. dentipes should be re-examined" (Guinot, 2007: 30). On the other hand, the gonopod of Davusia glabra turns out to be similar to the one of $P$. chabrus. These characters are therefore not consistent in the separation of the newly recognized genus Davusia and suggest a mosaic of characters within the genus Plagusia in its former sense.

More conclusive adult morphological characters to consistently separate two species of the genus Guinusia n. gen., G. chabrus and G. dentipes, from the species of Plagusia (and Davusia) have in fact already been provided much earlier by Miers (1878). He separated his first group consisting of Plagusia depressa, P. tuberculata (=P. squamosa), P. immaculata Lamarck, 1818, P. speciosa Dana, 1852, and P. glabra from his second group, with $P$. dentipes and $P$. chabrus, on the basis of the absence or presence of a "series of spines" on the upper margin of the ambulatory merus and, to a lesser extent, of the presence or absence of tubercles on the carapace. It is precisely these characters (figs. 3, 4) in addition to larval morphology (fig. 5) and molecular 


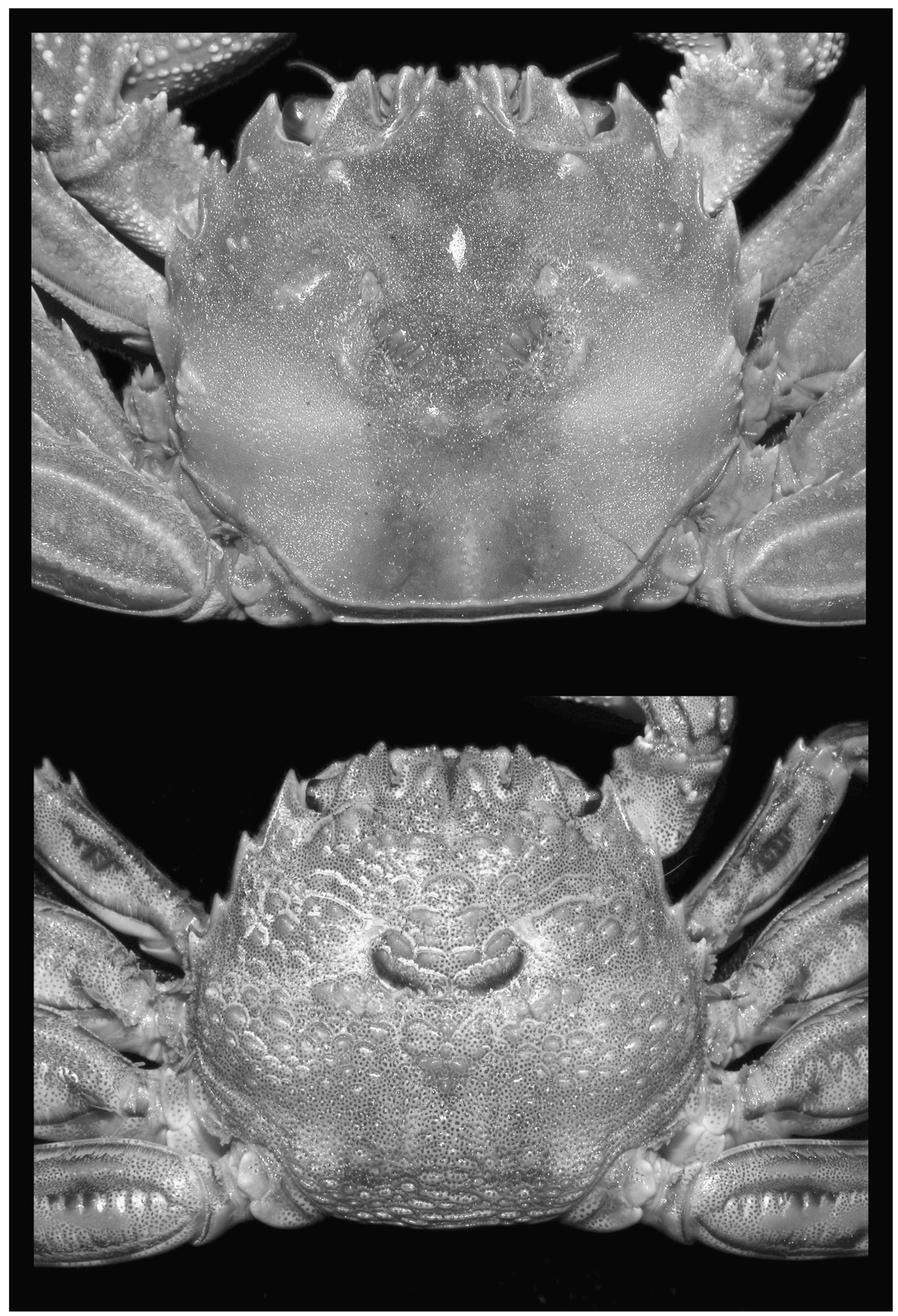

Fig. 4. Morphology of carapace structures in Guinusia gen. n. and Plagusia. Top, Guinusia dentipes (De Haan, 1835), Japan (SMF-24559); Bottom, Plagusia depressa (Fabricius, 1775), Ghana (SMF-34728). 


\section{TABLE II}

Morphological and meristic differences between zoeal and megalopal stages of those species of Plagusiidae with known larval data. Abbreviations: (-) no data; (?) zoea collected in plankton samples, number of stage attributed by the author; antenna type (A) refers to exopod present as a small simple seta, (B) refers to exopod less than 1/6 of the protopod length with 1-2 terminal setae, longer one never reaching the middle of protopod length; (C) refers to exopod longer than $1 / 6$ of the protopod length with small terminal spines and 2 terminal setae, longer one almost reaching the tip of the protopod [authorities of species names have been mentioned in the main text]

\begin{tabular}{|c|c|c|c|c|c|}
\hline \multirow[t]{2}{*}{ Species } & \multirow{2}{*}{$\begin{array}{c}\text { No. zoeal } \\
\text { stages }\end{array}$} & \multicolumn{2}{|c|}{ Zoeal stages } & \multicolumn{2}{|c|}{ Megalopa stage } \\
\hline & & $\begin{array}{l}\text { Antenna } \\
\text { type }\end{array}$ & $\begin{array}{c}\text { Setation of } 1^{\text {st }} \\
\text { maxilliped } \\
\text { basis }\end{array}$ & $\begin{array}{c}\text { No. segment } \\
\text { on exopod of } \\
3^{\text {rd }} \text { maxilliped }\end{array}$ & $\begin{array}{l}\text { No. cincinuli } \\
\text { on endopod } \\
\text { of pleopods }\end{array}$ \\
\hline $\begin{array}{c}\text { Euchirograpsus } \\
\text { americanus }\end{array}$ & $5(+6)$ & B & $2,2,2,2$ & - & - \\
\hline Guinusia chabrus & $12(?)$ & B & $2,2,3,3$ & - & - \\
\hline Guinusia dentipes & - & B & $2,2,3,2$ & 2 & $13-15$ \\
\hline Plagusia depressa & $6(?)$ & $\mathrm{C}$ & $2,2,2,2$ & 1 & 9 \\
\hline Plagusia speciosa & - & $\mathrm{C}$ & $2,2,2,2$ & - & - \\
\hline Plagusia squamosa & - & $\mathrm{C}$ & $2,2,2,2$ & 1 & $8-9$ \\
\hline Percnon abbreviatum & - & - & - & - & $11-15$ \\
\hline Percnon gibbesi & $6(?)$ & $\mathrm{A}$ & $2,2,3,2$ & $1^{(1)}$ & $13-17$ \\
\hline Percnon guinotae & - & - & - & - & $11-14$ \\
\hline Percnon planissimum & - & - & - & 1 & $11-14$ \\
\hline
\end{tabular}

(1) Cuesta \& Schubart, unpublished data.

datasets (figs. 1,2) that we here use as distinguishing characters for the new genus.

Supporting characters for separating the two species here included in Guinusia n. gen. from the remaining representatives of Plagusia were indeed found in the larval morphology, despite the fact that larval descriptions of Plagusiidae are incomplete and scarce (no larvae yet known for Davusia and Miersiograpsus, and only an incomplete description of the zoea of Euchirograpsus americanus, as opposed to published larval data for four out of seven recognized species of Plagusia). Zoeal data are known for P. chabrus (zoea I by Wear, 1970, and zoea V? and XII? by Wear \& Fielder, 1985), P. dentipes (zoea I by Terada, 1987), P. depressa (zoea I-V by Wilson, 1980), and $P$. squamosa (zoea I by Schubart et al., 2001). Included in the present study are the unpublished results (by J. Cuesta, H.-C. Liu \& C. D. Schubart) of the first zoea of a fifth species, $P$. speciosa. 

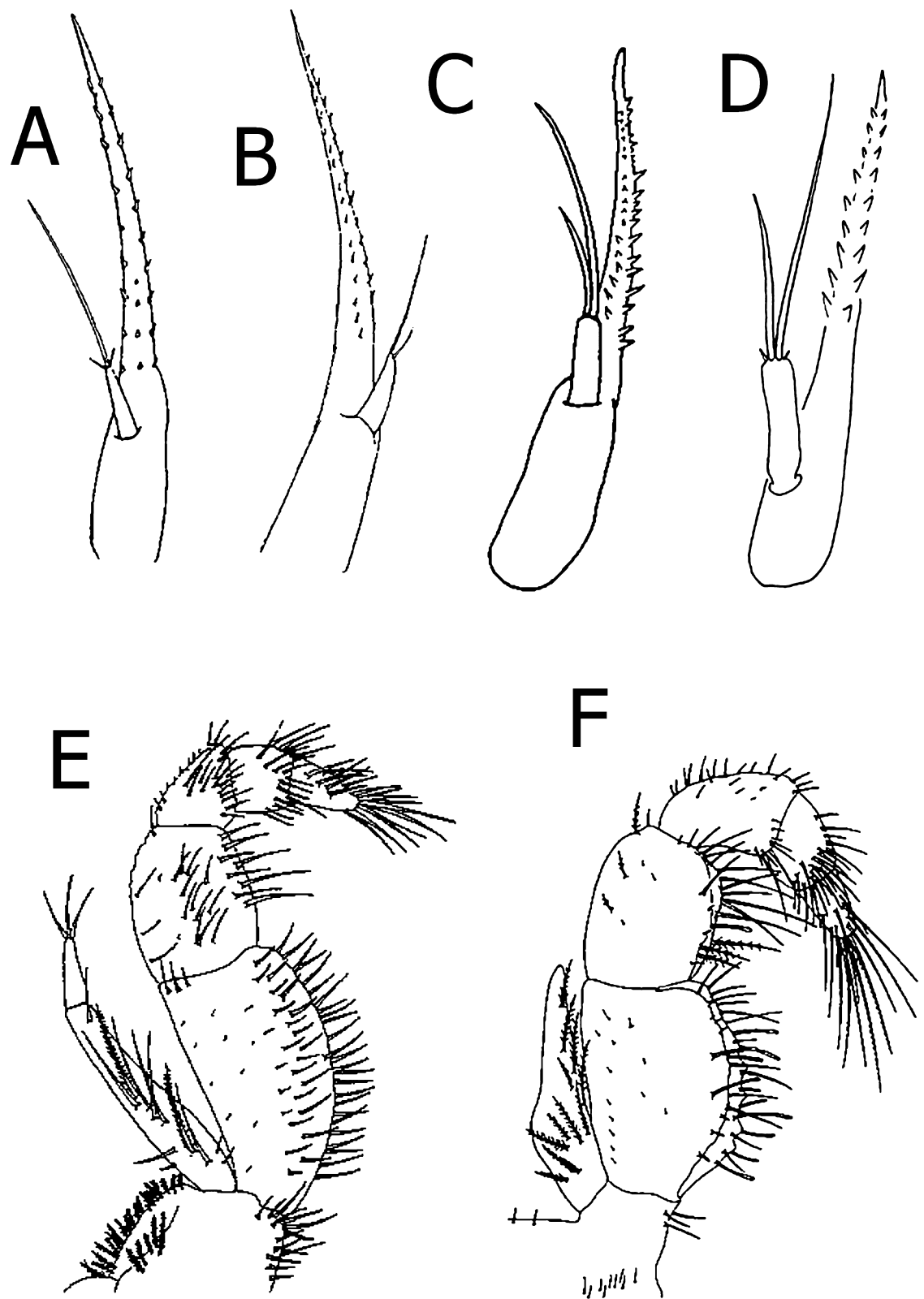

Fig. 5. Antennal morphology of zoea I of: A, Guinusia chabrus (Linnaeus, 1758); B, Guinusia dentipes (De Haan, 1835); C, Plagusia depressa (Fabricius, 1775); D, Plagusia speciosa Dana, 1852 (after Wear, 1970; Terada, 1987; Schubart et al., 2001; Cuesta, Liu \& Schubart, unpubl., respectively). Third maxilliped (detail of exopod) of the megalopa of: E, Guinusia dentipes; F, Plagusia depressa (after González-Gordillo et al., 2000; Schubart et al., 2001, respectively). 
All zoea I of Plagusia sensu stricto share a setal count of 2,2,2,2 at the basis of the first maxilliped, whereas Guinusia dentipes and G. chabrus have a 2,2,3,2 and 2,2,3,3 setal pattern, respectively. Another important difference is found in the antennal exopod, which is relatively shorter (less than $1 / 6$ of protopod length) in G. chabrus and G. dentipes, and ends in a long seta that can reach, as maximum size, half the protopod length, with two (G. chabrus) or one (G. dentipes) additional short setae. In the species of Plagusia sensu stricto, the exopod is longer (more than $1 / 6$ of protopod length) and with two long setae, the longer one reaching almost to the tip of the protopod and presenting minute terminal spines (not observed in G. chabrus and G. dentipes) (fig. 5).

The morphology of the megalopa stage also appears to be useful in distinguishing species of Guinusia from Plagusia. The megalopa has only been described for Guinusia chabrus (without details by Barnard, 1950; Wear, 1970; Wear \& Fielder, 1985), G. dentipes (several descriptions, the most detailed by González-Gordillo et al., 2000), Plagusia depressa (Schubart et al., 2001), and P. squamosa (Muraoka, 1965). Three characters show important differences that allow telling apart the megalopae of G. dentipes (and G. chabrus) from those of $P$. depressa and $P$. squamosa. Firstly, the exopod of the third maxilliped, is 2-segmented in G. dentipes, but unsegmented in P. depress $a$ and $P$. squamosa (no data available for G. chabrus). Secondly, the endopod of the pleopods has less than 10 (8 or 9) cincinnuli in P. depressa and $P$. squamosa, but more than 12 (13-17) in G. dentipes (no data available for G. chabrus). Finally, the rostrum is rather short and broadly bilobed in $G$. dentipes and G. chabrus, whereas it projects well forward and is bifid at the tip in P. depressa and P. squamosa.

Previous mtDNA phylogenies have included only one or two species of Plagusia (e.g., Schubart et al., 2001, 2006). The molecular trees generated for this study include all currently recognized species of Plagusia with the exception of Plagusia integripes Garth, 1973, from the Easter Islands, which is so far only known from the type. Morphological examination of the type specimen allowed the conclusion that the species should remain in the genus Plagusia based on the pattern of spines on the meri of the ambulatory legs. However, no amplifiable DNA could be obtained from it. The use of mitochondrial 16S rRNA and the nuclear histone $\mathrm{H} 3$ gene allowed both the recognition of intrageneric genetic distances and the construction of more robust gene phylogenies based on separate DNA sources, which should reflect the species' phylogeny. Three main clusters within Plagusia (sensu Schubart \& $\mathrm{Ng}, 2000$ ) could be recognized, one consisting of the type species $P$. depressa 
(Atlantic) in addition to P. squamosa, P. immaculata, and P. speciosa (IndoPacific). Schubart et al. (2001) documented morphological (adult and larval) and genetic differences between the allopatric P. depressa and $P$. squamosa, warranting the specific status of both. In the present analysis, however, the two sympatric Indo-Pacific species, $P$. squamosa, and $P$. immaculata, could not be genetically distinguished based on the fragment used, or histone H3. This could be due to a very recent separation event, which is not expressed in the analysed DNA. However, the main morphological difference between these two species is the setation surrounding the tubercles of the carapace and in the sulcae of the pereiopods, present in $P$. squamosa but absent in $P$. immaculata (see Schubart \& Ng, 2000). In most cases, this pubescence is easy to discern under a dissecting microscope, but some individuals have a faintly developed setation (C. Schubart, pers. obs.), so that we are inclined to consider these two species conspecific with a variable degree of pubescence. However a final decision on synonymy will have to await more comprehensive morphological study, and genetic comparisons with more variable markers (Schubart et al., in progress).

The genetically (and morphologically) most distinct of all former Plagusia species is Davusia glabra. The monotypic status of Davusia Guinot, 2007, is confirmed by the long branch with a single species at the tip (no close sister species). The molecular results indicate that Davusia glabra is phylogenetically basal to all other species of Plagusia and Guinusia n. gen.) and to the analysed species of Euchirograpsus and Miersiograpsus.

The third phylogenetic cluster consists of the two species, G. chabrus, and $G$. dentipes, which are here placed in the new genus Guinusia. Despite the clear morphological differences between these two species, they seem closely related genetically, forming the tip clades of a long branch with high confidence values. Also in this case, genetic distances to the remaining species of Plagusia are not lower than those between Guinusia and EuchirograpsusMiersiograpsus, the latter two genera forming a fourth monophyletic clade within the Plagusiidae.

The final putative member of the Plagusiidae is the genus Percnon. The present molecular data support the results of Schubart et al. (2000, 2006), in showing that Percnon species do not cluster close to the Plagusiidae, but represent a basal split within the Thoracotremata. The current study included three species, viz., Percnon gibbesi, P. planissimum, and P. guinotae Crosnier, 1965, and evidence from mitochondrial, and for the first time also from nuclear DNA (figs. 1,2), enforces support for an independent phylogenetic origin of 
Percnon, and strengthens the insight that it should not be maintained within the Plagusiidae. This differs from the conclusion by Ng et al. (2008), who gave the Percninae subfamily status within the Plagusiidae according to the following reasoning (their p. 219): "With regards to Percnon, DNA (Schubart et al., 1999 [2000]) and larval evidence (J. Cuesta, pers. comm.) have suggested that Percnon is different and doubtfully placed in the Plagusiidae. On the basis of adult morphology, we concur that Percnon species are highly derived, and have many unique generic apomorphies, probably related to their unusual habit of living subtidally on rock faces exposed to heavy wave action. These, combined with unusual sternal characters and the unique grapsoid condition of the male abdomen having only segments 3-5 fused, lead us to support the recognition of a separate subfamily, Percninae, a taxon first erected as a tribe by Števčić (2005)". However, the here provided combined evidence of mtDNA, nDNA, and larvae fully support separation of the Percnidae as a full family, suggesting that apparent adult morphological similarities to the Plagusiidae are due to convergence.

Data on the larvae of Percnon are, unfortunately, restricted to incomplete descriptions of the development of P. gibbesi (see Lebour, 1944; Paula \& Hartnoll, 1989) combining material reared in the laboratory and collected in the plankton, the megalopa stage of P. planissimum (see Muraoka, 1967), brief descriptions of the megalopa stages of P. abbreviatum (Dana, 1851), and P. guinotae and P. planissimum (see Hartnoll, 1992). Despite the limited data, significant differences in larval morphology also support exclusion of Percnon from the Plagusiidae. With regards to the zoeae, the antennal exopod has a small simple seta as in Grapsidae (sensu Schubart et al., 2002, see Cuesta \& Schubart, 1999), all the cephalothoracic spines are well developed (especially dorsal and rostral ones), covered by spinules, and the tips of these spines are extended in a lanceolate fashion. The abdomen is long, thin, and with a telson having long furcal arms and a deep cleft; this is a shape not found in any other "grapsoid" family and resembles that of Dorippidae and Dotillidae (see Paula, 1991; $\mathrm{Ng}$ et al., in press). The setation of the endopod of the maxilla of zoea I of $P$. gibbesi has a setation of 2,2, which in the zoea III changes to 2,3, and in zoea V and VI to 2,4 according to Paula \& Hartnoll (1989); this is very unusual and awaits confirmation. In all known brachyuran zoeae, this setation remains constant throughout development (Cuesta et al., 2006). The megalopae are also distinct, with 10 segments on the antennular flagellum (eight in Plagusiidae) and a trifid rostrum (bilobate or bifid at the tip in Plagusiidae).

In an mtDNA phylogeny of selected Thoracotremata, Schubart et al. (2006) found two representatives of the Plagusiidae (Plagusia depressa and Euchi- 
rograpsus americanus) clustering with low support among the Gecarcinidae, suggesting an apparent paraphyletic relationship of the latter family. Due to the low confidence values and limited number of taxa, this was not discussed in detail (except perhaps by $\mathrm{Ng}$ et al., 2008: 214), and Schubart et al. (2006: 196) concluded that "Further studies with all gecarcinid taxa and additional molecular markers are necessary to confirm their phylogenetic relationship and their position within the Thoracotremata". The molecular trees in the present study support monophyly of the Plagusiidae (now including all the genera) with confidence values always exceeding 0.95 posterior probability, and show no affinity to gecarcinid representatives. In contrast, the phylogenetic status of the Gecarcinidae as well as the basal relationships among the families of Thoracotremata remain unresolved (see also N. K. Ng et al., 2007). Very remarkable, however, is the close relationship of Ocypode and Ucides so that, in contrast to $\mathrm{Ng}$ et al. (2008), for the time being, we continue recognizing Ucides as member of the family Ocypodidae (and the Ucididae Števčić, 2005 a junior synonym of the Ocypodidae). Further studies are currently underway to resolve basal relationships among the Thoracotremata, including more conserved nuclear markers (28S and nuclear coding genes) (Schubart et al., in prep.; Landstorfer et al., in prep.).

The present study represents a comprehensive phylogenetic study of the Plagusiidae and has resulted in recognition of the new genus Guinusia and the establishment of a new phylogenetic understanding of relationships among four genera and 11 species of the family Plagusiidae. In order to make the Plagusiidae monophyletic we formally exclude Percnon and the subfamily Percninae from the Plagusiidae, and hereby recognize the independent family Percnidae Števčić, 2005.

Family PERCNIDAE Števčić, 2005 [new status]

Subfamily PerCNINAE Števčić, 2005 (see Ng et al., 2008)

Tribe PERCNINI Števčić, 2005

Type genus. - Percnon Gistel, 1848 (only genus in family).

Type species. - Acanthopus planissimus Herbst, 1804.

Other species. - Percnon abbreviatum (Dana, 1851), P. affine (H. Milne Edwards, 1853), P. gibbesi (H. Milne Edwards, 1853), P. guinotae Crosnier, 1965; P. sinense Chen, 1977.

Diagnosis. - Carapace conspicuously flattened; front with two antennal clefts, third maxillipeds with reduced exopod and lacking palp (shared with Plagusiidae); meri of walking legs always with several spines on dorsal crest, male abdomen with somites 3-5 fused (3-6 in Plagusiidae). 


\section{ACKNOWLEDGEMENTS}

We would like to thank Peter Castro, Bertrand Richer de Forges, Peter Davie, and Peter $\mathrm{Ng}$ for their invitation to contribute to this special volume of Crustaceana (and for comments on the first version), thus allowing us to honour Danièle Guinot. We also would like to express our gratitude to a number of colleagues who have contributed to previous studies of Plagusia and this way prompted our attention to this genus, among them predominantly Peter K. L. Ng, Hung-Chang Liu, Nacho González-Gordillo, and Shinyi Tsuchida. We are also greatly indebted to Alain Crosnier, Régis Cleva and the MNHN Paris, Pere Abelló and the Instituto de Ciencias Marinas, Barcelona, Peter J. F. Davie and the Queensland Museum Brisbane, Jody Martin and the Natural History Museum of Los Angeles County, Peter K. L. Ng and the Zoological Reference Collection of the Raffles Museum, Gary Poore and the Victoria Museum, Melbourne, Michael Türkay, Kristin Pietratus and the Senckenberg Museum Frankfurt, Darryl L. Felder, Rafael Robles, Emma Palacios Theil, Rudolf Diesel, Sara Fratini, Carsten H. G. Müller, and Peter Wirtz, for kindly photographing, donating or making available further specimens from their collections. Darryl Felder and Joe Neigel (University of Louisiana at Lafayette) and Jürgen Heinze (Universität Regensburg) are acknowledged for providing the laboratory facilities to generate some of the sequences. Most especially, we would like to thank Danièle Guinot for her important contributions to the field, for so many interesting discussions, and for her constant encouragement.

\section{REFERENCES}

Alcock, A., 1900. Materials for a carcinological fauna of India. No. 6. The Brachyura Catometopa, or Grapsoidea. Part II. Journal of Asiatic Society of Bengal, 69 (3): 279456.

BARNARD, K. H., 1950. Descriptive catalogue of South African decapod Crustacea. Annals of the South African Museum, 38: 1-837.

BeneCH, S. V., 1978. Ocean transport of a community of the grapsid crab Plagusia dentipes (De Haan, 1833). Crustaceana, 35: 104.

Colgan, D. J., C. Mclaughlia, G. D. F. Wilson, S. P. Livingston, G. D. EdgeCOMBE, J. MACARANAS, G. CASSis \& M. R. GraY, 1998. Histone H3 and U2 snRNA DNA sequences and arthropod molecular evolution. Australian Journal of Zoology, 46: 419-437.

Cuesta, J. A., G. Guerao, H.-C. Liu \& C. D. Schubart, 2006. Morphology of the first zoeal stages of eleven Sesarmidae (Crustacea, Brachyura, Thoracotremata) from the IndoWest Pacific, with a revision of larval characters of the family. Invertebrate Reproduction and Development, 49 (3): 151-173. 
Cuesta, J.A. \& C. D. Schubart, 1998. The first zoeal stage of Glyptograpsus impressus, with comments on the subfamilial arrangement of Grapsidae (Crustacea: Brachyura). Cahiers de Biologie Marine, 38: 291-299 [as 1997].

— — \& — , 1999. First zoeal stages of Geograpsus lividus and Goniopsis cruentata from Panama confirm consistent larval characters within the subfamily Grapsinae (Crustacea: Brachyura: Grapsidae). Ophelia, 51 (3): 163-176.

DANA, J. D., 1851. On the classification of the Crustacea Grapsoidea. American Journal of Science and Arts, (2) 12: 283-290.

- —, 1852. Crustacea. United States Exploring Expedition during the years 1838, 1839, 1840, 1841, 1842 under the command of Charles Wilkes, U.S.N., 13 (1): i-viii, 1-685. (C. Sherman, Philadelphia).

DAvie, P. J. F., 2002. Crustacea: Malacostraca: Eucarida (Part 2): Decapoda-Anomura, Brachyura. In: A. Wells \& W. W. K. Houston (eds.), Zoological Catalogue of Australia, 19.3B: i-xiv, 1-641. (CSIRO Publications, Melbourne).

Dawson, E. W., 1987. A key to the world species of Plagusia (Crustacea: Brachyura), with a new record of $P$. depressa tuberculata Lamarck from New Zealand. National Museum of New Zealand Records, 3 (4): 37-45.

GonZÁlez-Gordillo, J. I., S. Tsuchida \& C. D. Schubart, 2000. Redescription of the megalopa of Plagusia dentipes (Brachyura: Plagusiidae) from Japan. Crustacean Research, 29: 143-151.

GRIFFIN, D. J. G., 1968. The designation of a neotype for Cancer chabrus Linnaeus and the status of Plagusia capensis De Haan (Decapoda, Grapsidae). Crustaceana, 15 (2): 209213.

Guinot, D., 1978. Principes d'une classification évolutive des Crustacés Décapodes Brachyoures. Bulletin Biologique de la France et de la Belgique, 112 (3): 211-292.

— —, 1979. Données nouvelles sur la morphologie, la phylogenèse et la taxonomie des Crustacés Décapodes Brachyoures. Mémoires du Muséum national d'Histoire naturelle, (A, Zoologie) 112: 1-354.

- - 2007. A new genus of the family Plagusiidae Dana, 1851, close to Plagusia Latreille, 1804 (Crustacea, Decapoda, Brachyura). Zootaxa, 1498: 27-33.

Guinot, D. \& J.-M. Bouchard, 1998. Evolution of the abdominal holding systems of brachyuran crabs (Crustacea, Decapoda, Brachyura). Zoosystema, 20 (4): 613-694.

Hartnoll, R. G., 1992. Megalopae and early postlarval stages of East African Percnon (Decapoda: Brachyura: Grapsidae). Journal of Zoology, London, 228: 51-67.

Huelsenbeck, J. P. \& F. RonQuist, 2001. MrBayes: Bayesian inference of phylogenetic trees. Bioinformatics, 17: 754-755.

Latreille, P. A., 1804. Crustacés (1). Crustacea. Classe Septième. Tableau méthodique des Crustacés. In: Nouveau Dictionnaire d'Histoire Naturelle, 24: 123-127.

— - 1810. Considérations générales sur l'ordre naturel des animaux composant les classes des Crustacés, des Arachnides et des Insectes; avec un tableau méthodique de leurs genres, disposés en familles: 1-144. (F. Schoell, Paris).

LeBouR, M. V., 1944. Larval crabs from Bermuda. Zoologica, 29: 113-128.

MAN, J. G. DE, 1883. Carcinological studies in the Leyden Museum. No. 3. Notes of the Leyden Museum, 5 (15): 150-169.

Manning, R. B. \& L. B. Holthuis, 1981. West African brachyuran crabs (Crustacea: Decapoda). Smithsonian Contributions to Zoology, 306: i-xii, 1-379.

Martin, J. W. \& G. E. Davis, 2001. An updated classification of the recent Crustacea. Natural History Museum of Los Angeles County, Science Series, 39: 1-124. 
Miers, E. J., 1878. Revision of the Plagusiinae. Annals and Magazine of Natural History, (5) 1: $147-154$.

MURAOKA, K., 1965. On the post-larval stage of Plagusia depressa tuberculata Lamarck (Grapsidae). Research on Crustacea, 2: 83-90.

— , 1967. On the post-larval stages of Percnon planissimum (Herbst), Grapsidae. Research on Crustacea, 3: 61-67.

Ng, N. K., P. J. F. Davie, C. D. Schubart \& P. K. L. NG, 2007. Xenograpsidae, a new family of grapsoid crabs (Crustacea: Brachyura) associated with shallow water hydrothermal vents. Raffles Bulletin of Zoology, (Supplement) 16: 233-256.

NG, P. K. L., 1998. Crabs. In: K. E. CARPenter \& V. H. Niem (eds.), FAO Species identification guide for fishery purposes. The living marine resources of the western central Pacific, 2. Cephalopods, crustaceans, holothurians and sharks: 1045-1155. (Food and Agriculture Organisation, Rome).

NG, P. K. L., P. F. Clark \& J. A. Cuesta, in press. Establishment of a new subfamily for Shenius anomalus (Shen, 1953) (Decapoda, Brachyura, Dotillidae). Journal of Natural History, London.

Ng, P. K. L., D. Guinot \& P. J. F. Davie, 2008. Systema Brachyurorum: Part I. An annotated checklist of extant brachyuran crabs of the world. Raffles Bulletin of Zoology, (Supplement) 17: 1-286.

NG, P. K. L., C. H. WAng, P. H. Ho \& H. T. ShIH, 2001. An annotated checklist of brachyuran crabs from Taiwan (Crustacea: Decapoda). National Taiwan Museum Special Publications Series, Taipei, 11: 1-186.

PAUlA, J., 1991. The zoeal stages of the crab Medorippe lanata (Linnaeus, 1767) (Brachyura, Dorippidae) reared in the laboratory, and the larval characters of the Dorippidae. Journal of Natural History, London, 25: 75-89.

Paula, J. \& R. G. Hartnoll, 1989. The larval and post-larval development of Percnon gibbesi (Crustacea, Brachyura, Grapsidae) and the identity of the larval genus Pluteocaris. Journal of Zoology, London, 218: 17-37.

PosAdA, D. \& K. A. CRANDALl, 1998. MODELTEST: testing the model of DNA substitution. Bioinformatics, 14: 817-818.

Rathbun, M. J., 1918. The grapsoid crabs of America. U.S. National Museum Bulletin, 97: $1-461$, pls. $1-161$.

SChubart, C. D., 2009. Mitochondrial DNA and decapod phylogenies: the importance of pseudogenes and primer optimization. In: J. W. MARTin, K. A. Crandall \& D. L. FELDER (eds.), Decapod crustacean phylogenetics. Crustacean Issues, 18: 47-66. (Taylor \& Francis/CRC Press, Boca Raton, Florida).

Schubart, C. D., S. Cannicci, M. Vannini \& S. Fratini, 2006. Molecular phylogeny of grapsoid crabs (Decapoda, Brachyura) and allies based on two mitochondrial genes and a proposal for refraining from current superfamily classification. Journal of Zoological Systematics and Evolutionary Research, 44 (3): 193-199.

Schubart, C. D., J. A. Cuesta, R. Diesel \& D. L. Felder, 2000. Molecular phylogeny, taxonomy, and evolution of nonmarine lineages within the American grapsoid crabs (Crustacea: Brachyura). Molecular Phylogenetics and Evolution, 15 (2): 179-190.

Schubart, C. D., J. A. Cuesta \& D. L. Felder, 2002. Glyptograpsidae, a new brachyuran family from Central America: larval and adult morphology, and a molecular phylogeny of the Grapsoidea. Journal of Crustacean Biology, 22 (1): 28-44.

Schubart, C. D., J. I. González-Gordillo, N. Reyns, H.-C. LiU \& J. A. Cuesta, 2001. Are Atlantic and Indo-Pacific populations of the rafting crab, Plagusia depressa, distinct? New evidence from larval morphology and mtDNA. Raffles Bulletin of Zoology, 49 (2): 301-310. 
SChubart, C. D. \& P. K. L. NG, 2000. On the identities of the rafting crabs Cancer depressus Fabricius, 1775, Cancer squamosus Herbst, 1790, Plagusia immaculata Lamarck, 1818, and Plagusia tuberculata Lamarck, 1818 (Crustacea: Decapoda: Brachyura: Plagusiidae). Raffles Bulletin of Zoology, 48 (2): 327-336.

Sternberg, R. von \& N. Cumberlidge, 2000. Taxic relationships within the Grapsidae MacLeay, 1838 (Crustacea: Decapoda: Eubrachyura). Journal of Comparative Biology, 3 (2): 115-136 [as 1998].

ŠTEVČIĆ, Z., 2005. The reclassification of brachyuran crabs (Crustacea, Decapoda: Brachyura). Natura Croatica, 14 (supplement 1): 1-159.

Tamura K., J. Dudley, M. Nei \& S. Kumar, 2007. MEGA4: Molecular Evolutionary Genetics Analysis (MEGA) software version 4.0. Molecular Biology and Evolution, 24: 1596-1599.

TeradA, M., 1987. Zoeal forms of 14 species of crabs from Enshunada. Research on Crustacea, 16: 93-120.

UDEKEM D'ACOZ, C. D', 1999. Inventaire et distribution des crustacés décapodes de l'Atlantique nord-oriental, de la Méditerranée et des eaux continentales adjacentes au nord de $25^{\circ} \mathrm{N}$. Collection "Patrimoines Naturels", 40: 1-383. (Muséum national d'Histoire naturelle, Paris).

WEAR, R. G., 1970. Life-history studies on New Zealand Brachyura. 4. Zoea larvae hatched from crabs of the family Grapsidae. New Zealand Journal of Marine and Freshwater Research, 4 (1): 3-35.

Wear, R. G. \& D. R. Fielder, 1985. The marine fauna of New Zealand: Larvae of the Brachyura (Crustacea, Decapoda). New Zealand Oceanographic Institute Memoir, 92: 190.

Williams, A. B., 1984. Shrimps, lobsters, and crabs of the Atlantic coast of the eastern United States, Maine to Florida: 1-550. (Smithsonian Institution Press, Washington, D.C.).

WiLson, K. A., 1980. Studies on decapod Crustacea from the Indian River region of Florida. XV. The larval development under laboratory conditions of Euchirograpsus americanus A. Milne-Edwards, 1880 (Crustacea: Decapoda: Grapsidae) with notes on grapsid subfamilial larval characters. Bulletin of Marine Science, Miami, 30 (4): 756-775.

Wilson, K. A. \& R. H. Gore, 1980. Studies on decapod Crustacea from the Indian River region of Florida. XVII. Larval stages of Plagusia depressa (Fabricius, 1775) cultured under laboratory conditions (Brachyura: Grapsidae). Bulletin of Marine Science, Miami, 30 (4): 776-789.

First received 28 June 2009.

Final version accepted 13 August 2009. 